\begin{tabular}{lccc}
$\mathbf{V}$ & $\mathbf{A}$ & $\mathbf{I}$ \\
\hline & $\begin{array}{l}\text { ROCZNIKI HUMANISTYCZNE } \\
\text { Tom LXIX, zeszyt } 1-2021 \\
\text { DOI: htps://doi.org/10.18290/rh21691-7 }\end{array}$ \\
& &
\end{tabular}

RADOSŁAW GRZEŚKOWIAK

\author{
DECYMA BAROKOWYCH PRZEKŁADÓW PIEŚNI \\ O MARNOŚCI ŚWIATA \\ (INC.: „CUR MUNDUS MILITAT SUB VANA GLORIA”) \\ STUDIUM ŹRÓDŁOZNAWCZE
}

Pochodząca z XIII wieku pieśń o inc.: „Cur mundus militat sub vana gloria” stanowi jeden z najpopularniejszych utworów poświęconych marności doczesnego świata. Autor pisanego rymowaną łaciną hymnu nie jest znany. W XVII i XVIII wieku tekst funkcjonował jako dzieło włoskiego franciszkanina Jacopone da Todi i na ziemiach polskich cieszył się dużą popularnością (czego dowodzą nie tylko liczne kopie ${ }^{1}$, ale także fakt, iż dawne zapisy nutowe przekazały różne melodie, na które był śpiewany ${ }^{2}$ ), nie doczekał się jednak spolszczenia w ramach antologii Hymny, prozy i kantyka kościelne Stanisława Grochowskiego z 1599 r. czy Pieśni katolickie nowo reformowane [...] z lacińskich na polskie przełożone, którą przed 1639 r. opracował Stanisław Serafin Jagodyński. Brak tłumaczenia rozpowszechnionego drukiem na początku XVII wieku okazał się zbawienny w skutki, między latami 1647 a 1747 zaowocował bowiem wysypem doraźnych przekładów, które składają się na pokaźny i zróżnicowany zbiór.

Łaciński tekst powielano w tym czasie w różnych wariantach, na które przede wszystkim składały się wersje pozbawione niektórych strof (dawni

\footnotetext{
Prof. dr hab. RADOSŁAW GRZEŚKOWIAK - Instytut Filologii Polskiej Uniwersytetu Gdańskiego; adres do korespondencji: ul. Wita Stwosza 55, 80-308 Gdańsk; e-mail: radoslaw.grzeskowiak@ug.edu.pl; ORCID: https://orcid.org/0000-0002-6160-9982.

${ }^{1}$ Oprócz wspomnianych niżej zapisów kopie łacińskiej pieśni zachowały się też w innych szlacheckich sylwach (np. rkpsy Biblioteki Narodowej, sygn. IV 3047, k. 203v; BOZ 855, k. 47v; BOZ 866, s. 40).

${ }^{2}$ Trzy znane mi notacje muzyczne zapisane w XVIII wieku na terenie Rzeczypospolitej przynoszą trzy różne melodie (Katalog nr 89; Idaszak nr 400, 519; Maciejewski nr 5).
} 
polscy thumacze nie znali choćby w. 13-24 oryginału $)^{3}$. Także brzmienie poszczególnych kwartyn bywało różne. W połowie XVII wieku popularna była np. wersja z dittografią, która wieńczący 9. strofę wers: „In ictu oculi claudentur omnia" (w. 36) powtarzała na końcu kolejnej kwartyny (w. 40), zastępując oryginalną lekcję: „Et ducunt homines ad dura devia”4. Taki zniekształcony zapis był podstawą przekładu Jana Libickiego (por. nr 1: 4, w. 4, i 5, w. 4), Samuiła Piotrowskiego-Sitnianowicza (por. nr 3: w. 16 i 20), Wespazjana Kochowskiego (por. nr 5: w. 24 i 27-28) i twórcy thumaczenia skopiowanego w sylwie z lat 1665-1679 (por. nr 6: w. 24 i 28).

\section{Przekład Jana Libickiego z 1647 r. (inc.: „Czemu świat hołduje chwale i próżności”)}

Po 26 marca 1647 r. (data aprobacji cenzorskiej) wydane zostało spolszczenie Poema de vanitate mundi niemieckiego jezuity Jacoba Baldego pióra sekretarza królewskiego Jana Libickiego. W dedykacji dwudziestotrzyletniej magnatce polski autor dał wierny przekład pięciu strof łacińskiej pieśni (w. 1-4, 25-40), dopełniając go szóstą własnej inwencji (Balde 3-4):

\section{Jaśnie Oświeconej Księżnie,}

Jej Mości P[ani] Gryzeldzie z Zamościa Wiśniowieckiej, wojewodzinej ruskiej, swojej wielce $\mathbf{m}$ [iłoś]ciwej paniej, Jan Libicki, sekretarz J[ego] K[rólewskiej] M[ości], przy oddaniu uniżonych posług swoich zdrowia dobrego i wszelkiego szczęścia od Pana Boga życzy

1.

Czemu świat hołduje chwale i próżności,

Którego szczęśliwość jest w niestateczności?

Tak prędko ozdoby jego odbiegają,

Jak garki na ziemię, gdy z rąk upadają.

2 .

Powiedz, gdzie Salomon wielce wywyższony

Abo kędy Samson, wódz niezwyciężony,

Abo gdzie Absolon przedziwnej gładkości

Bądź wdzięczny Jonatas wielkiej przyjemności.

${ }^{3}$ Za wspólny mianownik umożliwiający porównanie przekładów przyjąłem 13-zwrotkową wersję wydaną przez Henry’ego Spitzmullera (Poésie latine 968-971) i spolszczoną przez Marka Starowieyskiego (Muza łacińska 556-559 - tu także uwzględniający filiacje biblijne komentarz rzeczowy do pieśni).

${ }^{4}$ Zob. np. kopie Piotrowskiego-Sitnianowicza i rkpsu Biblioteki Książąt Czartoryskich, sygn. 377 , s. 741 . 


\section{3.}

Kędy cesarz odszedł z państwa wysokiego

Bądź bogacz siedzący u stołu pysznego,

Abo gdzie Cycero, mówca tak wysoki,

Abo Arystotel dowcipem głęboki?

4.

Tak zacni panowie, tak rzeczy stworzone,

Tak święci biskupi, tak państwa zmocnione,

Tak świata książęta dostatku wielkiego

Schodzą - w mgnieniu oka ujźrzysz umarłego.

5.

Tak krótkie uciechy, tak świata próżności,

Jako cień człowieczy jego wesołości,

Które szczęśliwości wieczne ukradają,

A same we mgnieniu oka przemijają.

6.

Takie ja próżności piórem opisuję,

A Waszej Książęcej Mości ofiaruję

$Z$ ochotą, nadzieją tak ubezpieczony,

Że dla prawdy samej nie będę wzgardzony5.

Balde w dziele o marności chwały świata dał rozbudowany katalog sław, które bezpowrotnie przeminęły (strofy 30-56). Swą dedykacją Libicki odwołał się do klasycznego tekstu, który ów motyw rozsławił, wskazując na żywotność marnościowej tradycji przekładanego poematu. Choć pracę podporządkował innym celom, strofy przełożył $\mathrm{z}$ wyraźnym szacunkiem dla oryginału, m.in. zachowując ich sylabiczną formę.

\section{Anonimowy przeklad z polowy XVII wieku}

(inc.: „Czemu świat tak barzo próżnej chwale służy”)

Kolejne spolszczenie skopiowane zostało m.in. w kodeksie z materiałami z czasów panowania Zygmunta III i Władysława IV. Jego właściciel po dziesięciozwrotkowym zapisie oryginału umieścił przekład pt. Pieśń o marności świata tego. Gorszą kopię tej samej wersji tekstu zawiera sylwa łowczego gostyńskiego Krzysztofa Dobińskiego z pierwszej dekady XVIII wieku. Oba przekazy pozwalają na miarodajne odtworzenie wspólnego źródła:

Czemu świat tak barzo próżnej chwale służy,

Którego szczęśliwość na krótki czas płuży?

\footnotetext{
${ }^{5}$ Poprawiam usterki metryczne 1,4: Jako, 3,4: Arystoteles, 4,4: we mgnieniu.
} 
Tak prędko przemija jego panowanie, Jak jedno naczynie nasłabsze gliniane.

5 Wierz więcej pisaniu na ledzie rytemu Niżli w obietnicach światu obłudnemu. Więcej wierz powieści człeka niewiernego, Niż szczęściu, rozkoszy świata omylnego.

Gdzie, proszę, są oni, co jemu wierzyli,

10 Co się w delicyjach jego zanurzyli?

Gdzie mądry Salomon, gdzie on król wspaniały,

Gdzie śliczny Absolon, Samson barzo śmiały?

Gdzie możni królowie, gdzie oratorowie,

Biskupi, książęta, zacni monarchowie,

15 Co się rozkoszami świata unosili?

We mgnieniu też oka wszytkiego pozbyli.

Tak pewna uciecha świata mizernego, Jako cień człowieka w drogę idącego.

O nędzny człowiecze, gadziny potrawo,

20 O marna próżności, robactwa zabawo,

Czmuż tak łakomie pragniesz wysokości?

Czemu z turbacyją nabywasz godności?

Nie wiesz, że cię z tego śmierć okrutna złupi, A od jej srogości nikt cię nie odkupi?

25 Twa pompa po śmierci w bryle ziemie będzie, A sprosna gadzina zewsząd cię obsiędzie.

Nie wierz obietnicom już żadnym światowym, Czyń dobrze, pókiś żyw, nalepiej takowym.

Myślą swą wzbijaj się aże pod niebiosy,

30 Tam bowiem po śmierci będą [t]we rozkoszy, Gdy za straszną trąbą wnet z grobu wyskoczysz, A osądzon, Bóg wie, gdzie się tam obrocisz ${ }^{6}$.

Pod koniec przekładu tłumacz zaczął odchodzić od oryginału, amplifikując go wzmiankami o rekwizytach charakterystycznych dla barokowej vanitas (w. 25-26, 30-32), co biorąc pod uwagę powodzenie jego pracy, spotkać się musiało z uznaniem odbiorców.

${ }^{6}$ Rkpsy Biblioteki Książąt Czartoryskich, sygn. 377, s. 741-742, oraz Biblioteki Narodowej, sygn. III 6652, k. 538v (brak tu w. 9-12, 27-30, a pozostałe wpisano w kolejności: w. 1-8, 17-18, 1316, 21-24, 19-20, 25-26, 31-32). Poprawiam lekcję w. 30: swe rozkoszy. 
Przy czym nie jest to pełny tekst przekładu. W dwóch tomach obszernego rękopiśmiennego zbioru pieśni, który w latach 1711-1732 kolekcjonował ksiądz Franciszek Walenty Ruthen (zob. Wöhler), znalazło się miejsce nie tylko dla oryginału hymnu, ale także dla jego kilku spolszczeń. Ruthenowy zapis omawianego thumaczenia stanowi kontaminację: trzy końcowe zwrotki pochodzą z redakcji wydanej w Młotku duchownym (por. nr 4), jednak początkowe należą do przekładu o inc.: „Czemu świat tak barzo próżnej chwale służy”:

Czemu świat tak barzo próżnej chwale służy,

Którego szczęśliwość na krótki czas płuży?

Tak prędko przemija jego panowanie,

Jak jedno najsłabsze naczynie gliniane.

5 Wierz więcej pisaniu na ledzie rytemu

Niźli w obietnicach światu obłudnemu:

Fałszywy w rozkoszach snem przemijających,

Kłamliwy w uciechach niedługo trwających.

Gdzie mądry Salomon, gdzie on król wspaniały,

10 Abo gdzie Samson jest, wódz on bardzo śmiały?

Dokąd poszedł cesarz sławny w panowaniu,

Dostatni w bankietach, dwo[r]ny w częstowaniu?

Powiedz, gdzie Tullijusz języka wolnego

I Arystoteles dowcipu wielkiego.

15 Gdzie możni królowie i tryumfatorowie,

Biskupi, książęta, mocni monarchowie?

Tak wielkie potęgi, które w uszach słyną,

Za czasy krótkiemi w mgnieniu oka miną.

Ta chwała doczesna jako wiatr ginąca

20 I jako kwiat polny lub trawa więdniąca.

O próżny człowiecze, gadziny potrawo,

O marna próżności, robactwa zabawo,

Pielgrzymem ty jesteś, nie panem światowym;

Czyń dobrze, pókiś żyw - najlepiej ubogim? ${ }^{7}$.

Nieznane opublikowanej wyżej wersji w. 7-8, 11-14, 17-20 mają swój odpowiednik w oryginale (w. 11-12, 29-32, 35-38), co dowodzi, że stanowią pochodną autorskiej redakcji przekładu. Dwie wersje dalej nie wyczerpują

\footnotetext{
${ }^{7}$ Rkps Biblioteki Diecezjalnej w Pelplinie, sygn. 594, k. 8r-10v (drugiej paginacji): [Rhythmus $b[$ eati] Iacoponi $[\ldots]$ de vanitate mundi] Taż pieśń po polsku w tymże tonie. Poprawiam lekcję w. 12: dwony.
} 
wiedzy na jej temat. W obu brak znanej z oryginału wzmianki o wiernym druhu Dawida Jonatanie (w. 28), co nie oznacza, że tłumaczenie było jej pozbawione. Oto jeszcze jeden, mocno zniekształcony przekaz tego spolszczenia $\mathrm{z}$ drugiej połowy XVII wieku, który z jednej strony pomijał szereg zwrotek, z drugiej został amplifikowany czterowersowym zakończeniem, nieznanym oryginałowi i pozostałym odpisom. Po pierwszych czterech wersach, zasadniczo zgodnych z brzmieniem przedrukowanych wersji, kopia ta przynosiła następujący ciąg dalszy:

5 Gdzie, proszę, Salomon, niegdy król wspaniały,

Gdzie Samson waleczny, hetman bardzo sławny,

Gdzie śliczny Absolon nader urodziwy,

Gdzie wdzięczny Jonatan i syn też szczęśliwy?

Gdzie cesarz Julijusz w sławnym panowaniu,

10 Gdzie bogacz rozkoszny w pilnym godowaniu?

Gdzie, proszę, Cycero, krasomówca wielki,

Gdzie Arystoteles nauki głębokiéj?

Gdzie potentatowie, gdzie senatorowie,

Biskupi nawyższy, gdzie bohatyrowie,

15 Królowie, książęta, gdzie ich świetne pułki?

W mgnieniu ci wszyscy skończyli swe wieki.

O, świecie obłudny, świecie zły, zdradliwy,

Wszystkiem a wszystkiem [tyś] jest bardzo szkodliwy!

Przez cię szczęścia wszystkie ludzkie upadają:

20 Zgiń, przemiń, oszuście - wszyscyć to zadają ${ }^{8}$.

Gubiący rymy zapis pieśni o przemijaniu światowej chwały kumulacją błędów narosłych w wyniku oralnej i rękopiśmiennej transmisji tekstu zaświadcza o tezie, do której przez stulecia przekonywał oryginał. Tak wysoki stopień erozji tekstu przy jednoczesnej konsekwencji przestrzegania dwunastozgłoskowego metrum uznać należy za pochodną popularności melicznej. Spolszczenie w wanitatywnym repertuarze drugiej połowy XVII wieku musiało być szlagierem, co sprawia, że trudno miarodajnie restytuować jego oryginalną postać.

${ }^{8}$ Wiersz jako Druga pieśń cyklu Pieśni o śmierci był zapisany w zatraconym rkpsie dawnej Biblioteki Załuskich, sygn. Pol.Q.IV.30 (Croisette van der Kop 214-215 - poprawiam lipometrię w. 18: wszystkiem jest). 


\section{Przeklad Samuila Gawrylowicza Piotrowskiego-Sitnianowicza (Symeona z Polocka) sprzed 1653 r. (inc.: „Czemu świat hołduje sławie niestatecznej”)}

Wśród młodzieńczych prób poetyckich Samuiła Gawryłowicza PiotrowskiegoSitnianowicza, późniejszego Symeona z Połocka, zapisanych w brulionie z czasów nauki w Akademii Wileńskiej (1650-1653), znalazło się m.in. spolszczenie łacińskiego hymnu. Na jednej stronie kodeksu student jezuickiej uczelni zapisał oryginał (brak tu w. 5-24, 45-48) i dwa własne tłumaczenia, na język cerkiewnosłowiański oraz polski:

Czemu świat hołduje sławie niestatecznej,

Której szczęście nie ma godziny bezpiecznej?

Tak prędko jej władza ponosi odmianę,

Jak łatwo się kruszy naczynie gliniane.

5 Powiedz, gdzie Salomon sławą uwielbiony

Albo gdzie jest Samson, wódz niezwyciężony,

Gdzie śliczny Absolon udatnej postawy,

Gdzie luby Jonatas każdemu łaskawy.

Dokąd dziś ustąpił on cesarz wielmożny

10 Albo świetny bogacz, rozkosznik niezbożny?

Powiedz, gdzie Tullijus z słodkością wymowy,

Gdzie Arystoteles z dowcipem swej głowy?

Gdzie ona moc, państwa i sławne krainy,

Królewstwa, prałactwa? Już wszędzie szczerbiny.

15 Jak wiele włodarzów, książąt wiele było,

We mgnieniu źrzenice wszytko się zmieniło.

Niedługi to jarmark tegoświetnia sława,

Jako cień człowieczy rozkosz - jej ustawa,

A zawsze dobro nam wieczyste umyka,

20 We mgnieniu źrzenice wszytko się zamyka.

O karmio robactwa, o ziemny popiele,

O roso, o próżność, chlubisz się tak śmiele,

Sam nie wiesz, jeśli dzień oglądasz jutrzejszy;

Staraj się, wszytkim byś mógł być wygodniejszy.

25 Nie kładź przeto ni w czym ufności uprzejmie,

Bo coć świat darował, prędko to odejmie.

$\mathrm{O}$ wieczne staraj się, umysłem bądź w niebie;

Szczęśliwy, który świat zarzuci za siebie9.

\footnotetext{
${ }^{9}$ Rkps Rosyjskiego Państwowego Archiwum Akt Dawnych w Moskwie, Kolekcja Drukarni Synodalnej, font 381, op. 1, nr 1800, k. 139r. W autografie pierwotną lekcję w. 24: Staraj się, jak możesz, byś byt wygodniejszy, poeta zastąpił nową redakcją. Najpoprawniejsza dotąd transkrypcja dostępna była w: Nikolayev 226-227.
} 
Ruski poeta swobodnie władał polszczyzną i wierszem sylabicznym. Jego przekład, zachowujący wzorzec metryczny oryginału, należy do bardziej udanych. Budził on uznanie już u współczesnych, znane jest bowiem jego ukraińskie thumaczenie $\mathrm{z}$ drugiej połowy XVII wieku, wiernie powtarzające translatorskie rozwiązania Symeona z Połocka (Zosim 187-201).

\section{Anonimowy przekład sprzed 1656 r. (inc.: „Czemu świat w próżnościach tak sobie smakuje”/,Czemu się świat próżnej chwale wysługuje”)}

Kolejne spolszczenie w zniekształconej postaci włączone zostało do wydanego po 9 kwietnia 1656 r. (data aprobacji cenzorskiej) druku Młotek $d u$ chowny w sercach ludzkich tor Chrystusów drelujacy autorstwa kanonika włocławskiego Pawła Mirowskiego. Pierwszą księgę dzieła zwieńczyło tak zaanonsowane spolszczenie wanitatywnej pieśni (Mirowski $E_{8} r-E[!]_{1} v$ ):

Światu jako zdrajcy wierutnemu nie wierz. A kogo farbiczką i pięknością oszust ten nie oszukał? Maszkarać to wszytko - zedrzy ją, szczerą próżność, sprosność, smród i wstęchłą zgniełość nadybiesz. Podepcz tę lichotę, zapaś się w podróż ku niebu, która abyć mielij i raźniej zeszła, możesz sobie dla melankolijej onę błogosławionego Jakopona dumę po polsku w tę drogę pryśpiewywać:

Czemu się świat próżnej chwale wysługuje,

Której oka w mgnieniu szczęście ulatuje?

Tak łacno się kruszy panosza światowa,

Jak czcza z kruchej gliny praca garcarzowa.

5 Wierz raczyj literom na ledzie pisanym

Niż świata kruchego zdradom farbo[w]anym.

Oszust, gdy co płaci-ć pod pstr[ą] larwą cnoty,

Udaje tak prawdę zdradzieckiej roboty.

Przysiągłbyś, żeć się już nie zmieni na wieki?

10 Nie wierz, do mrugnieniać nie dotrwa powieki.

Powiedz, gdzie Salomon, ona Pańska głowa,

Albo gdzie się działa siła Samsonowa?

Gdzie gładki Absolon, gdzie krasna twarz jego,

Gdzie pieszczek Jonatas lica kochanego,

15 Gdzie się Cezar podział, strach ponośny świata,

Gdzie bogaczów obiad i od złota szata?

Sławny gdzie Tullijusz, gdzie jego wymowa,

Gdzie Arystoteles, nauczeńsza głowa?

I po nas spytają: „,Gdzie, co tę pieśń złożył

20 A dla bogomyślnych swej prace przyłożył?”. 
Tak wielu gdzie świetne papieżów korony,

Gdzie cesarzów, królów najaśnie[j]sze trony,

Tłum czapek prałackich, kardynalskie szaty

I biskupich twarzy gdzie poczet bogaty?

25 Zlicz, co świat miał książąt, co paniąt, co chwały

I jak możne komu państwa hołdowały.

Przebóg, gdzież to wszytko oraz się podziało?

Wszytko się we mgnieniu oka rozsypało.

O nieszczęsny świecie, jak krótkie twe gody:

30 Płonieją, jak płonie cień ludzkiej urody.

O złodzieju jawny, kradniesz żołd wieczności,

Jak owce pchasz ludzie do wiecznych ciemności.

Wierzże tu, człowiecze, pyszń się z nim pospołu,

O strawo robacza, o worze popiołu,

35 O gnoju gromado śniegiem nastrzępiona,

O maro, o bryło rosą zagnieciona.

Czyń dobrze, gdy możesz - wszytkich łapaj sobie,

Nie wiesz, czy nie jutro w ciemnym legniesz grobie.

$\mathrm{Z}$ tej pompy światowej, która tak drożeje,

40 Pismo się jak z zdziebłka siana święte śmieje

I waży ją jak list, który wiatr szamoce,

Albo jak zamknioną rosę na obłoce:

Jak płochy wiatr, gdzie chce, liście czcze powiewa,

Tak światowa pompa żywot nasz podwiewa.

45 Nie mów, że to twoje, co możesz utracić,

Coć świat poborgował, toć dybie połapić.

Obróć myśl ku górze, serce miej na niebie,

Szczęśliwyś, jeśli świat depczesz, nie on ciebie ${ }^{10}$.

Ciekawa amplifikacja (w. 19-20) nie pochodzi raczej od anonimowego tłumacza, nie znają jej bowiem inne przekazy. Odmienną wersję spolszczenia przechowały kancjonały krakowskich karmelitanek bosych, jeden z przełomu XVII i XVIII wieku, drugi z roku 1722:

Czemu świat w próżnościach tak sobie smakuje,

Którego uciecha jak cień ulatuje?

Tak bywa moc jego i siły zniszczone,

Jak z gliny naczynia bywają skruszone.

${ }^{10}$ Poprawiam błędy w. 4: z skruchej, w. 6: farbonanym, w. 7: pod pstra, w. 15: straach, w. 22: najaśniesze. Trzy ostatnie strofy tej wersji, skontaminowane z początkiem odmiennego thumaczenia, skopiowano w rkpsie Biblioteki Diecezjalnej w Pelplinie, sygn. 594, k. 10v (drugiej paginacji); por. nr 2. 
$5 \quad$ Wierz raczej literom na ledzie pisanym

Niż świata chytrego zdradom farbowanym:

Oszuka w nagrodzie i w zmyślonej cnocie,

Nie wierz i bynamniej złej jego robocie.

Wierz bardziej, komu chcesz, i ludziom fałszywym,

10 Niż świata chytrego rozkoszom zdradliwym.

Wierz i snom omylnym, i wszelkiej chytrości,

Wierz bardziej i słowom pełnym wszelkiej złości.

Powiedz, gdzie Salamon, owa Pańska głowa,

Albo gdzie teraz jest siła Samsonowa,

15 Gdzie piękny Absalon, gdzie gładka twarz jego,

Gdzie pieściek Jonatas wejrzenia pięknego.

Gdzie króla majestat - strach nieznośny świata, Gdzie bogaczów obiad i od złota szata,

Sławny gdzie Tullijusz, gdzie jego wymowa,

20 Arystotelesa gdzie subtelne słowa?

Tak wiel[u] gdzie świetnych papieżów korony, Cesarzów gdzie, królów najaśniejsze trony, Thum czapek prałackich, kardynalskie szaty I biskupich infuł gdzie poczet bogaty?

25 Zlicz, co miał świat książąt, co paniąt, co chwały I jak możne komu państwa hołdowały.

Przebóg, gdzież to wszystko oraz się podziało?

Wszystko się we mgnieniu oka rozsypało.

O zdradliwy świecie, tak krótkie twe gody

30 Mijają, jak bystre szumiejące wody.

O sławny złoczyńco, ty kradniesz z wieczności,

Jak owce pchasz ludzie do wiecznych ciemności.

Wierzże mu, człowiecze, wiąż się z nim pospołu.

O strawo robaków, o worze popiołu,

35 O ziemi gromado śniegiem przytrząśniona,

O maro, o bryło rosą zagnieciona,

Czyń dobrze, gdy możesz - Boga jednaj sobie,

Nie wiesz, czy nie jutro w ciemnym legniesz grobie.

Tę próżność, którą świat tak bardzo szacuje,

40 Pismo święte źdźbłem być siana pokazuje

Albo suchym listem, który wiatr porywa,

To tak człowiek prędko żywota pozbywa.

Więc nie mów, że twoje, co możesz utracić:

Co świat dziś pożyczył, jutro chce popłacić. 
45 Obróć serce w niebo świętymi myślami,

Szczęśliwy, kto zły świat zdeptał z marnościami ${ }^{11}$.

Choć karmelitańskie kancjonały są późniejsze niż druk Młotka duchownego, to przekazują brzmienie bliższe autorskiej wersji spolszczenia. Jest to najobszerniejszy z barokowych przekładów. Jego twórca również nie znał trzech strof oryginału (w. 13-24), ale thumacząc pozostałe, nie zawsze respektował zasadę wersyfikacyjnej ekwiwalencji. Odpowiednik jednej kwartyny oryginału (w. 41-44) ma u niego sześć wersów (w. 33-38), drugiej (w. 33-36) osiem (w. 21-28). Także w edycji Mirowskiego odpowiednik kwartyny (w. 45-48) rozciągnięty został do sześciowersu (w. 39-44). To wielosłowie nie przysłużyło się artystycznej jakości translacji.

\section{Przekład Wespazjana Kochowskiego sprzed 1674 r. (inc.: „Czemu świat na próżną tak jest sławę chciwy”)}

$\mathrm{Z}$ datą dzienną 6 października $1674 \mathrm{r}$. ukazał się najważniejszy zbiór liryczny Wespazjana Kochowskiego, Niepróżnujące próżnowanie ojczystym rymem. Jako pieśń II 11 wydano tu Omylność świata tego z adnotacją: „Ex Latino: »Cur mundus militat« etc.” (Kochowski 93-94):

Czemu świat na próżną tak jest sławę chciwy,

Której widok tylko skutek nieszczęśliwy?

We mgnieniu tłucze się ten pozór kłamliwy Jak garniec gliniany gwałtu niecierpliwy.

5 Więcej wierz na lodzie pismu wyrytemu Aniż w obietnicach słowu światowemu Na tym się omylić przyszło niejednemu, Sam sobie omylny, zdradliwy każdemu.

Więcej ufaj mowie, chociaż w prawdę głodnej,

10 Więcej snów znikomych rozkoszy łagodnej,

Więcej i w jesieni płanecie pogodnej,

Niż świeckiej fortunie pochlebstwem ozdobnej.

Pytaj, gdzie Salomon mądrością wsławiony, Gdzie Samson potężną ręką niezwalczony,

15 Kędy jest Absalon w swej gładkości onéj, Gdzie wdzięczny Jonatas wszytkim ulubiony.

${ }^{11}$ Rkpsy Biblioteki Jagiellońskiej, sygn. BJ 3643/I, k. 103r-v, Biblioteki Karmelitanek Bosych na Wesołej w Krakowie, sygn. 275, s. 226-229: Światowa manijera. Poprawiam lekcję w. 21: wiele. 
Gdzie z Julijuszowej carska mitra głowy,

Kędy Antoniego aparat gotowy,

Gdzie wzięty Cycero z swej słodkiej wymowy,

20 Gdzie Arystoteles mądry w rzecz, nie słowy?

Tak możne królestwa przyszły ku zginieniu,

Potężni królowie u śmierci w więzieniu,

Prałaci, panowie w tymże legli cieniu,

Wraz wszytko upada w jednym oka mgnieniu.

25 Jak świecę zagasisz, aż ciemny mrok padnie,

Puścisz w wodę kamień, aż utonie snadnie,

Tak chwała światowa w momencie upadnie

I z ludzkich się oczu zdradziecko wykradnie.

O kupo popiołu, o karmio gadziny,

30 O kwiatku więdnący jednejże godziny,

Mniemasz, by zacniejszy nie był nad cię iny,

Otoć wnet do grobu sprawią przenosiny.

Gardźże tą próżnością, o człecze mizerny,

Boć ten świat zdradliwy i fałsz w nim niezmierny.

35 O wieczność się staraj, gdzie byt nieśmiertelny,

Co nam wszytkim racz dać, Boże miłosierny ${ }^{12}$.

Przekład Kochowskiego nie uwzględnił kilku strof oryginału (w. 13-24 i 45-48) i na tle prezentowanych translacji jest dość swobodny. W wyliczeniu sław tego świata nieokreślonego bogacza poeta wymienił na Marka Antoniusza, czyniąc aluzję do szczytu kosztowności uczty, na której Kleopatra wypiła rozpuszczoną w occie drogocenną perłę ${ }^{13}$. Także w innych miejscach, by uwypuklić moralizatorskie przesłanie, nie wahał się ubarwiać przekładanego tekstu porównaniami własnej inwencji (por. w. 11, 25-26, 31-34).

\section{Anonimowy przekład sprzed 1679 r.}

(inc.: „Czemu świat znikomej marności hołduje”)

W sylwie, do której wojski horodelski Andrzej Moszyński w latach 1665-1679 wpisywał teksty publicystyczne i dokumenty, został też skopiowany oryginał interesującej nas pieśni, a po nim anonimowy przekład:

\footnotetext{
${ }^{12}$ Poprawiam dittografię w. 3: ten pozór ten.

${ }^{13}$ Informację zawdzięczał poeta Pliniuszowi Starszemu (Historia naturalis IX 39,119-121); por.: „I na ucztę twą, Antoni, / Kleopatra perłę roni / topiąc, ceny tej bez mała, / że milijon kosztowała" (Kochowski 190-191: III 22: Hojność wedlug miary, w. 25-28).
} 
Czemu świat znikomej marności hołduje,

Którego świeboda wiatrem ulatuje?

Moc i sława jego, o, jak prędko ginie,

Dłużej więc lepione trwa z gliny naczynie!

5 Wierz więcej literom na ledzie wyrytym

Niż świeckim pieszczotom fałszem zdrad pokrytym.

Świat kłamca zdradliwy, gdyć co obiecuje,

Nie wierz mu - nic nie ma, a cudzem szafuje.

Raczej bym uwierzył fałszerzom kłamliwym

10 Aniżli na świecie lubościom zdradliwym.

Świat fałszerz w rozkoszach jak sen ulubionych,

Fałszywy w naukach próżnością złudzonych.

Powiedz mi, Salamon gdzie jest znamienity,

Powiedz, gdzieli Samson wojną nieprzebity.

15 Gdzie się podział Absolon twarzy urodziwéj,

Gdzie wdzięczny Jonatas w wierze osobliwy?

Gdzie cesarz on, który hardzie rozkazował,

Gdzie bogacz on, który często biesiadował?

Powiedz, gdzie Cycero w mowie nawdzięczniejszy,

20 Gdzie Arystoteles on najdowcipniejszy.

Tak wielcy panowie, tak dzieła szerokie,

Tak sławni królowie, tak głowy wysokie,

Tak zacne książęta, tacy monarchowie

W momencie zginęli. O, kto to wypowie,

25 Jako jest na świecie śliskie powodzenie,

Jak prędko niszczeje wszelkie dobre mienie,

Które nas z wiecznego królestwa odziera,

A we [m]gnieniu oka do piekła zabiera?

O strawo robakom, o prochu, szalejesz,

30 O roso, o próżność, czemuż tak hardziejesz?

Ato nie wiesz n[awet], czy jutra doczekasz.

Czyń dobrze, gdy możesz; czyń, ach, czego czekasz?

Sław[ę], którą ludzie na świecie zacz mają,

W Świętym Piśmie kwiatem, sianem nazywają,

35 Bo jako kwiat suchy wiatru snadnie co wi[o]nie,

Tak szczęście człowieka prędziuchno opłonie.

Więc temu nie dufaj, co możesz utracić:

Świat raczej wydziera to, czym chce zbogacić.

Myśl, radzęć, o Bogu twoim, o wieczności;

40 Szczęśliwy, kto świató[w] podeptał marności ${ }^{14}$.

${ }^{14}$ Rkps Biblioteki Uniwersytetu Warszawskiego, sygn. 68, k. 231v-232r: [De vanitate mundi] Polonice. Poprawiam lekcje w. 28: we gnieniu, w. 31: nie wiesz, nie wiesz, w. 33: Stawa, w. 35: co wianie, w. 40: światom. 
Nieznany skądinąd przekład, którego podstawą również był zapis pozbawiony w. 13-24 (różny jednak od tego, który skopiował Moszyński), jest dziełem uzdolnionego autora. Tam, gdzie łaciński tekst był niejednoznaczny, tłumacz pozwalał sobie na pewną swobodę, w pozostałych przypadkach wiernie trzymając się oryginału. Jego dzieło zdradza też biblijną erudycję: odpowiednik wersu: „In ictu oculi clauduntur omnia” w spolszczeniu przybrał postać: „A we [m]gnieniu oka do piekła zabiera” (w. 28) pod wpływem wersetu: „Prowadzą w dobrach dni swoje, a we mgnieniu oka do piekła zstępują" (Hi 21,13). Podobne zabiegi dobrze świadczą o literackiej kulturze tłumacza.

\section{Anonimowy przekład z przelomu XVII i XVIII wieku (inc.: „Z czego się wynosisz, próżna chlubo świata”)}

W kancjonale, na przełomie XVII i XVIII wieku spisanym w radomskim konwencie bernardynów przez bliżej nieznanego brata Franciszka (Trościński 107-108 i 122), wraz z łacińskim oryginałem znalazł się nieznany skądinąd przekład pieśni:

Z czego się wynosisz, próżna chlubo świata,

Gdyż się twoja sława jako dym rozlata?

Tak prędko się thucze twa mocy potęga,

Jak garniec u zduna, który on wyciąga.

5 Gdzież, proszę, jest sława króla Salomona,

Gdzie niezwyciężona moc ona Samsona?

Gdzie się dział Absolon niegdy światu śliczny,

Gdzie miły Jonatas wszystkiem barzo wdzięczny?

Nie widać cesarza rozkazującego,

10 Nie widać w bogactwach opływającego

Ani krasomówc[y] Tullego mądrego,

Ni Arystotela dowcipu bystrego.

Panowie radni i dostatki wielkie,

Infuły biskupie i królewstwa wszelkie,

15 I wielcy książęta, ich buta wysoka -

Wszystko to niszczeje prze zemknienie oka.

$\mathrm{O}$, jako nietrwałe światowe godności,

Równo z cieniem jego mijają radości,

Dla których traciemy szczęście wiekuiste,

20 A za to w katownie wpadamy ogniste!

Potrawo robaków, zgniłej ziemie sztuko

Do rosy podobna, czemuś tak wysoko

Wznosił[a]ś się, nie wiedząc, czy jutra doczekasz?

Czyń dobrze każdemu, póki czas dobry masz. 
25 Bo chwałę światową, która w takiej wadze,

Pismo z polnym kwieciem w równej cenie kładzie,

A jako list $\mathrm{z}$ drzewa wiatr prędko porywa,

Tak ludzką ozdobą krótkość czasu zrywa.

Nie dowierzaj temu, co możesz utracić,

30 Bo co świat da komu, nazad trzeba wrócić.

O wiecznym szczęściu myśl, serce wnieś do nieba,

Szczęśliwy, komu się świata bać nie trzeba ${ }^{15}$.

Zapisany w kodeksie tekst łaciński obejmuje 9 kwartyn (brak w. 9-24), a w stosunku do niego przekład pomija drugą strofę (w. 5-8). Obie wersje pieśni skopiowano pod pięciolinią, pozbawioną co prawda nut, ale już taki zapis dowodzi, że metrycznie zgodny z oryginałem przekład śpiewany był na tę samą melodię. Choć mamy do czynienia z dziełem domorosłego wierszopisa (czego dowodzi choćby spora liczba rymów męskich czy niedokładnych), dbał on o wierność tłumaczenia. Tylko jeden znany odpis sugeruje, że jego przekład nie był popularny i raczej nie opuścił murów klasztornych (nie przypadkiem do kancjonałów karmelitanek bosych trafiły inne tłumaczenia).

\section{Anonimowy przekład z początku XVIII wieku (inc.: „Pod znakiem próżnej chwały czemu świat wojuje”)}

Właściciel sylwy gromadzącej materiały polityczne i literackie z lat 1620-1747 skopiował w niej również anonimowe tłumaczenie hymnu (w zapisie oryginału brak było w. 13-24) pt. Przyjaźń świata w niestateczności podejźrzana:

Pod znakiem próżnej chwały czemu świat wojuje,

Którego powodzenie $\mathrm{z}$ wiatrem ulatuje?

Tak prędko jego możność pada się i psuje,

Jak się garnek rzucony w sztuki rozlatuje.

5 Więcej na topniejącym wierz lodzie pisaniu

Niż[eli] fałszywemu świata zachęcaniu:

Zawodźca w obietnicach, tylko się pokrywa

Cnotą, która u niego i gościem nie bywa.

Ufać raczej przystoi szkłu, choć nietrwałemu,

10 Niż światu sukcesa ci obiecującemu,

\footnotetext{
${ }^{15}$ Rkps Biblioteki Diecezjalnej w Sandomierzu, sygn. L 1684, s. 334-335: [De mundo et eius contemptu] Polonice. Poprawiam lekcje w. 11: krasomówcę, w. 12: Ani Arystotelesa, w. 23: Wznosiłeś się, w. 25: władze. Za życzliwe udostępnienie fotokopii przekazu serdecznie dziękuję dr. hab. Grzegorzowi Trościńskiemu.
} 
Niżeli fałszom jego na kształt snu zmyślonym,

Rozkoszom i próżnościom, zabiegam szalonym.

Powiedz, gdzie jest Salomon przedtym zawołany

Albo Samson, ów sławny wódz nieprzełomany.

15 Kędy piękny Absalon wejźrzenia cudnego,

Jonatas gdzie, mający miłość u kożdego?

Kędyż jest cesarz państwy władnący na świecie,

Gdzie bogacz, gdzie rozkosznik ustawny w bankiecie?

Powiedz, gdzie jest Tullijusz języka mownego

20 Albo Arystoteles rozumu bystrego?

Tak wiele sławnych hersztów, rzeczy znamienitych,

Tak wielebnych prałatów, królestw niedobytych,

Tak wiele książąt świata, pompa tak wysoka -

Wszystko to pominęło w jednym mgnieniu oka.

25 O, tak-że to krótki fest chwały świata tego:

Uciechy jego na kształt cieniu człowieczego,

Które wieczne rozkoszy gwałtem wydzierają,

Złą drogą wiedąc, ludzi w przepaść wieczną pchają!

O pokarmie robactwa, biednej ziemie bryło,

30 O cna próżności, jakby nad ciebie nie było,

Wynosisz się, nie wiedząc, jutro czy-li twoje.

Czyń dobrze, pókiej zmysły masz w całości swoje.

Tę świecką chwałę, co ją tak sobie szacuje

Człowiek, Pisma świętego tekst sianem mianuje,

35 A jak ów listek, który lada wiatr porywa,

Jest życie ludzkie, które śmierci łupem bywa.

Zgubie podległej nie zow żadnej twojej rzeczy,

Gdyć coć świat dał, odebrać znowu ma na pieczy.

Niech się myśl twa ma w górę, serce w niebo mierzy,

40 Szczęśliwy, kto tym światem o ziemię uderzy ${ }^{16}$.

Pisany trzynastozgłoskowcem przekład nie miał przeznaczenia melicznego (nie można go śpiewać na melodię oryginału), lecz wyłącznie literackie, i spośród zgromadzonych odznacza się największą precyzją w oddawaniu znaczeniowych niuansów łacińskiego tekstu.

${ }^{16}$ Rkps Biblioteki Zakładu Narodowego im. Ossolińskich we Wrocławiu, sygn. 6607/II, s. 1108-1109. Poprawiam usterkę metryczną w. 6: Niż fatszywemu. 


\section{Anonimowy przeklad sprzed $1716 \mathrm{r}$.}

\section{(inc.: „Czemu pod chorągwią pychy świat hołduje”)}

W zatraconej dziś kolekcji melicznej, którą w latach 1702-1716 gromadził jezuicki poeta Dominik Rudnicki, znajdowała się również pieśń o inc.: „Czemu pod chorągwią pychy świat hołduje" ${ }^{17}$. W przypadku tego utworu zniszczenie manuskryptu nie jest dużą stratą, gdyż przekład ów, powstały najpewniej w drugiej połowie poprzedniego stulecia ${ }^{18}$, w XVIII i XIX wieku był pieśnią często przedrukowywaną w katolickich kancjonałach. Spośród ośmiu wykorzystanych przekazów tekstu z lat 1732-1871, siedem pochodzi od wspólnego zniekształconego przodka, w którym brakowało w. 11-12, a w. 9 był hipermetryczny. Tylko jedno wydanie nie powtarza tych usterek, a w paru przypadkach (np. w. 14, 29) przynosi tekst bliższy oryginałowi, jest to jednak późny przedruk z 1802 r., niewolny od zniekształceń tekstu i modernizacji. Pieśń została w nim wydana pt. Życia ludzkiego marność (,Cur mundus..." $b[$ eati] Iacopon[i]) (Śpiewnik 585):

Czemu pod chorągwią pychy świat hołduje,

Którego fortunom niestatek panuje?

Tak słaba potęga i takiej odmiany, Jak w ręku niepewnych garnek jest gliniany.

5 Więcej wierz literom na lodzie pisanym Niż świata nadziejom obłudą nadzianym: Nas, ludzi, samemi snami świat zabawia, Nikczemne obłudy niby to coś stawia.

Więcej zwodziciele mogą znaleźć wiary,

10 Niż kłamstwem kradnące nieba wieczność mary.

Nie wierz wszelkiej świata pomyślnej lubości,

Wszystko to jest marność i próżność próżności.

Gdzież mądry Salomon, dziw świata wszystkiego,

Gdzie Samson, w swej sile nie znając równego,

15 Gdzie złote kędziory są Absalonowe,

Gdzie owo spoźrzenie miłe Jonatowe?

Gdzie cesarz Julijusz, pan niezwyciężony,

Gdzie bogacz workami zewsząd obłożony,

Gdzie Tullijusz, główny ów ojciec wymowy,

20 Gdzie Arystoteles, mąż dowcipnej głowy?

${ }^{17}$ Zatracony rkps Biblioteki Załuskich, sygn. Pol.Q.XVI.97, k. 38v-39r (Peretts, Zametki 16).

${ }^{18}$ Władimir Pierietc odnotował zapis przekładu w zatraconym rkpsie Biblioteki Załuskich, sygn. Pol.Q.XVII.212, k. 519v-521v, z końca XVII wieku (Peretts, Istoriko-literaturniya izsledovaniya 151). 
Gdzie są wielcy owi świata potentaci,

Przemożni królowie, czcigodni prałaci,

Książęta i walnych rycerzów wodzowie?

Wszystkie się wielkości skryły w trupiej głowie,

25 Jak jest krótkie święto chwały świata tego,

Rozkoszy podobne do cienia lekkiego,

Co niemądre oczy łatwo omamiają,

A wieczne prawdziwe szczęście wydzierają.

O karmo robactwa, o prochu zbutwiały,

30 O kropelko rosy, o kwiatku nietrwały,

Nie pewieneś jutra, a ważysz się wiele?

Czyń dobrze, pókić Bóg pozwala być w ciele.

Wszystkę tę, która jest, światowa ozdoba

Do zwiędłego kwiecia Pismo przypodoba:

35 Spada kwiat, a siano do ognia zbierają,

Wszystkie w oka mgnieniu te pompy ustają.

Strzeżże się, byś obłud w twych dobrach nie liczył, W lada dzień ci wydrze, czegoć świat pożyczył.

Miej wieczność w baczeniu, duszy twej życzliwy,

40 Kto umie świat wzgardzić, ten stokroć szczęśliwy ${ }^{19}$.

W podstawie przekładu brakowało w. 13-24, pozostałe przełożono stosunkowo wiernie z zachowaniem metrum oryginału.

${ }^{19}$ Za pozostałymi przekazami poprawiam lekcje w. 3: takie, w. 25: krótkie światto, w. 36: Wszystkim. Inne wykorzystane przekazy: pozbawiony k. tyt. kancjonał z początku XVIII wieku, egz. Biblioteki Jagiellońskiej, sygn. 926 I, s. 519-522; rkps PAN Biblioteki Kórnickiej, sygn. 41, s. 940-941 (nowej foliacji): Pieśń o marności świata. „Cur mundus militat” etc. po polsku; Pieśni katolickie [1754] 538-540; Pieśni nabożne [1799] 397-400. Lekcje wariantowe (pierwszy przekaz oznaczam: „1700”, drugi: „1732”, pozostałe datami wydania: „1754” i „1799”): w. 7-8: Istnemi nas snami świat w tym życiu łudzi, / nikczemna obłuda oszukiwa ludzi 1700, Istnemi snami nas [nas snami (1799)] ludzi świat na jawié, / gdy próżne obludy na ksztalt czegoś sławi 1732-1799; w. 10: kradnace miła wieczność kłamstwem 1700, w. 14: narodu strach filistyńskiego 1700-1799, w. 16: mite wejrzenie znikto 1700-1799, w. 19: stawny on 1700, zacny on 1799, w. 21: oni wielcy 1700-1799, w. 23: mężnych 1700-1799, w. 25: krótkie święto jest chwała 1700 1732, w. 27: oczy niemadre 1700-1799, w. 28: dobra ukradaja 1700-1799, w. 29: Pokarmie robaków 1700-1799, w. 30: rosy kropelko 1700-1799, w. 31: pewnieneś jutra, cóż się ważysz 1700-1799; pewien jutra, cóż tak się ważysz 1732-1754; w. 34: kwiecia zwiędlego 1700-1799, w. 35: Opada kwiat, siano 1700-1799, w. 36: znikaja 1700-1799, w. 37: Strzė̇, żebyś tych 1700-1754, w. 38: Lada w dzień 1700-1754, w. 39: w pamięci 1700-1799, w. 40: umiat światem wzgardzić 1732-1754, tym światem gardzi 1700-1799. Późniejsze przedruki (np. Pieśni nabożne [1817] 431-433; Pieśni nabożne [1829] 414-416; Zbiór pieśni nabożnych [1871] 979-980) nie wnoszą nowych danych tekstowych. 


\section{Anonimowa parafraza sprzed $1732 \mathrm{r}$. \\ (inc.: „Dlaczegóż, świecie, kochasz się w marności”)}

Do dwóch tomów zbioru religijnych pieśni, który kolekcjonował ksiądz Ruthen, trafiła Pieśń o marności świata, która z czasem zasiliła też drukowane kancjonały katolickie. W odróżnieniu od poprzednich nie jest ona thumaczeniem oryginału, lecz jego zgrabną adaptacją:

Dlaczegóż, świecie, kochasz się w marności

I serce swoje kładziesz w trupie kości?

W urodzie, w wygodzie, także i w gładkości,

Przesypiasz, zasypiasz oczy swe w próżności.

$5 \quad$ Która uroda, także i wygoda

Upływa prędko jako bystra woda:

Twa cera mizera słaba jest wygoda,

Zwiędnieje, zmarnieje w twarzy twej jagoda.

Mądry filozof z rzymskim oratorem

10 Kędy są wszyscy? Poszli jednym torem.

Ubogi nie drogi, śmierć nie zna purpury,

Wyrzyna, wycina jako z chojca kury.

Szczęśliwy, który umiał światem wzgardzić,

A duszy swojej o zbawieniu radzić.

15 Do nieba potrzeba na wieczność pamiętać,

Próżności, marności światowej zaniechać.

Więc się co prędzej wszyscy zgromadzajcie,

A do szczęśliwych met już pospieszajcie,

Bo to tam szczęśliwość na wieki trwać będzie,

20 Od ciebie twe szczęście nigdy nie odejdzie ${ }^{20}$.

Wygląda na to, że i tym razem zapis znany Ruthenowi nie obejmował całości parafrazy. Rękopiśmienne śpiewniki krakowskich karmelitanek bosych przechowały odpisy wersji, którą jedna z konsekrowanych kopistek opatrzyła tytułem Pieśń o marności świata (początek i śrzodek). Obejmuje ona trzy wersy strofy pierwszej (w. 1-3) i strofę czwartą (w. 13-16), między którymi znalazła się część zwrotki nieznanej Ruthenowi, mającej jednak swój odpowiednik w oryginale:

${ }^{20}$ Rkpsy PAN Biblioteki Kórnickiej, sygn. 41, s. 923: Pieśń o marności świata, oraz Biblioteki Diecezjalnej w Pelplinie, sygn. 594, k. 11v-12v (drugiej paginacji): Pieśń o marności świata; Zbiór pieśni nabożnych [1871] 977-978: [O marnościach światowych] Pieśń III. 
Salomonowa wymowa wsławiona,

Absalonowa uroda pieszczona,

Zginęła, zwiędnęła jak trawa zielona ${ }^{21}$.

Pomijając ostatnią strofę, która nie ma analogii w łacińskim oryginale (brak rymów wewnętrznych sugeruje, że może to być obca interpolacja), pozostałe zgrabnie go streszczają. Wanitatywny wywód, który już na wstępie ziemski przepych zredukował do „trupich kości”, dość nieoczekiwanie wsparł czarnoleski autorytet - w w. 11-12 wpleciony został cytat z Epitafijum Kosowi Kochanowskiego (Fraszki 14: I [32], w. 3-4):

Śmierć nie zna złota i drogiej purpury,

Mknie po jednemu, jako z kojca kury.

Pisana pod dyktando zasad poesis artificiosa parafraza starała się nie tyle zatrwożyć treścią, ile przykuć uwagę formalnymi efektami, w drugim dystychu strofy, mającym postać dwunastozgłoskowca $(6+6)$, przedśredniówkowy hemistych rozpada się bowiem na dwa trójzgłoskowe elementy spięte żeńskim rymem $(3 a+3 a+6 b / / 3 c+3 c+6 b)$.

Cel został zrealizowany z nawiązką, gdyż wiele wskazuje na to, że admiratorem parafrazy był autor Uwag Śmierci niechybnej, Józef Baka. Łasy na chwytliwe formuly i rymy innych poetów (Nawarecki 23-34), najwyraźniej zachwycił się też rozwiązaniami Pieśni o marności świata. Echa zestawień: „Zwiędnieje, zmarnieje” (w. 8) czy „Wyrzyna, wycina” (w. 12) wybrzmiewają w Młodym uwadze (Baka $\mathrm{D}_{3}$ r: Młodym uwaga, w. 5-11):

Cny młodziku, migdaliku,

Czerstwy rydzu, ślepowidzu,

Kwiat mdleje, więdnieje.

Być w kresie, czerkiesie.

Ej, dziateczki, jak kwiateczki

Powycina was, pozrzyna

Śmierć kosą z lat rosą

- a do frazy: „Do nieba potrzeba” (w. 15) jezuicki twórca wracał kilkakrotnie ${ }^{22}$.

\footnotetext{
${ }^{21}$ Rkpsy Biblioteki Jagiellońskiej, sygn. 3640/I, k. 99v: Pieśń o marności świata, 3645/I, k. 18v: Pieśn o marności świata, 3650/I, k. 49r: Pieśń o marności świata (początek i śrzodek).

22 Por. Uwaga Śmierci wszytkim stanom stużąca, w. 29 i 35; Uwaga nikczemności świata, w. 86 (Baka $D_{1}$; F $\left.F_{6}\right)$.
} 
Być może zaciągnięte $\mathrm{w}$ omawianej adaptacji długi nie sprowadzały się wyłącznie do przejęcia owych spojonych rymem zestawień. U autora Pieśni o marności świata Baka mógł także podpatrzeć ekwiwalencję trójzgłoskowych szeregów syntaktycznych, którą uczynił jedną z dystynktywnych cech stylu $U_{w a g^{23}}$, a analogiczną rymotwórczą sztuczkę (żeńskie rymy wiążące trzyi czterozgłoskowe hemistychy) wypromował na fundament swej ulubionej strofy-truchła, która choć wygląda jak regularna zwrotka, to w głośnej lekturze rozpada się na spięte żeńskim rymem metryczne kikuty (Grześkowiak 111-116).

To nie przypadek, że na ziemiach Rzeczypospolitej Obojga Narodów renesans średniowiecznej pieśni o marności świata przypadł na czasy baroku. Twórcy epoki skupionej na eskalacji wanitatywnego dyskursu umieli docenić przesłanie niegdysiejszego arcydzieła, nasycając je własnymi fantazmatami ulotności ludzkiej egzystencji (np. nr 2, w. 25-26: „Twa pompa po śmierci w bryle ziemie będzie, / a sprosna gadzina zewsząd cię obsiędzie”; nr 9, w. 24: „Wszystkie się wielkości skryły w trupiej głowie"). Poza parafrazą (nr 10) i jednym tłumaczeniem (nr 8) wskazane tu przekłady przestrzegały oryginalnego metrum, rzadkiego w polskiej poezji dwunastozgłoskowca (6+6), co dowodzi, że o popularności pieśni zadecydowała jej stała obecność w religijnym repertuarze melicznym poświadczona przez kancjonały kompilowane od XVII po XIX wiek.

\section{BIBLIOGRAFIA}

\section{PODMIOTOWA}

[Baka, Józef]. Uwagi Śmierci niechybnej, wszytkim pospolitej. [Wilno] 1766.

Balde, Jacob. Sen żywota ludzkiego. Tłum. Jan Libicki. Kraków, Franciszek Cezary, 1647.

Croisette van der Kop, Anna. „Pokłosie z rękopisów petersburskich. Dawne pieśni polskie”. Pamiętnik Literacki, 1913, ss. 206-217.

Kochanowski, Jan. Fraszki. Kraków, Jan Januszowski, 1584.

Kochowski, Wespazjan. Niepróżnujące próżnowanie ojczystym rymem... Kraków, Wojciech Górecki, 1674: „Lyrica” polskie.

[Mirowski, Paweł]. Młotek duchowny w sercach ludzkich tor Chrystusów drelujący. Gdańsk, Dawid Rhete, 1656.

\footnotetext{
${ }^{23} \mathrm{Na}$ tę cechę stylu Baki zwrócił uwagę Paweł Bukowiec: „Ekwiwalentyzacja jako zasada łączenia słów w syntagmatyczne szeregi przynosi w rezultacie: synonimię (»obfite, sowite«, »tratuje, morduje«), współbrzmienia zmierzające w stronę homofonii (»mantele, manele«, »osiecze, opiecze«), rozmaite paralelizmy morfologiczne i paralelizmy form składniowych" (Bukowiec 79), który traktował ją jako nieznaną skądinąd stylistyczną manierę Uwag Śmierci niechybnej.
} 
Pieśni katolickie wedtug obrzędów Kościoła ś[więtego] rzymskiego... Kraków, Drukarnia Akademii Krakowskiej, 1754.

Pieśni nabożne na adwent, Narodzenie, post, Zmartwychwstanie i inne święta uroczyste Jezusa... Supraśl, Drukarnia bazylianów, 1799.

Pieśni nabożne na święta uroczyste podtug porządku Kościoła ś[więtego] rzymskokatolickiego na cały rok zebrane... Wilno, Drukarnia bazylianów, 1817.

Pieśni nabożne na święta uroczyste wedlug porządku Kościoła świętego rzymskokatolickiego na cały rok zebrane... Grodno, Drukarnia Zymela, 1829.

Śpiewnik. „Qui cantat, bis orat”, oprac. Pankracy Folwarski. Kraków, Maciej Dziedzicki, 1802.

Zbiór pieśni nabożnych katolickich do użytku kościelnego i domowego, oprac. Szczepan Keller. Pelplin, Drukarnia Stanisława Romana, 1871.

\section{PRZEDMIOTOWA}

Bukowiec, Paweł. Metronom. O jednostkowości poezji „nazbyt” rytmicznej. Wydawnictwo Uniwersytetu Jagiellońskiego, 2015.

Grześkowiak, Radosław. „Bramka Górskiego. O ubezwłasnowolnieniu staropolskich autorów przy wyborze podstawy krytycznego wydania”. Terminus, nr 2, 2007, ss. 103-122.

Idaszak, Danuta. Grodzisk Wielkopolski. Katalog tematyczny muzykaliów. Musica Igellonica, 1993.

Katalog tematyczny rękopiśmiennych zabytków dawnej muzyki w Polsce, t. 1, z. 6, oprac. Elżbieta Głuszcz-Zwolińska, Polskie Wydawnictwo Muzyczne, 1983.

Maciejewski, Tadeusz. „Melodie z bernardyńskiego rękopisu 386/R”. W kręgu dawnej poezji, Instytut Wydawniczy PAX, 1983, ss. 159-220.

Muza łacińska. Antologia poezji wczesnochrześcijańskiej i średniowiecznej (III-XIV/XVw.), oprac. Marek Starowieyski, Zakład Narodowy im. Ossolińskich, 2007.

Nawarecki, Aleksander. Czarny karnawat. „Uwagi śmierci niechybnej” księdza Baki-poetyka tekstu i paradoksy recepcji. Zakład Narodowy im. Ossolińskich, 1991.

Nikolayev, Sergey. „Stikhotvoreniye Yakopone da Todi «O suyete mira» v russkih perevodah XVII v.” Trudy Otdela drevnerusskoy literatury, 1996, ss. 224-236.

Peretts, Vladimir. Istoriko-literaturniya izsledovaniya i materialy, t. 1, cz. 1. Tipolitografya F. Vaysberga, P. Gershunina, 1900.

Peretts, Vladimir. Zametki i materialy dlya istorii pesni v Rossii. Tipografya Imperatorskoy Akademii Nauk, 1901.

Poésie latine chrétienne du Moyen Âge (IIIe-XVe siècle), textes recueillis, traduits et commentés par Henry Spitzmuller, Desclée de Brouwer, 1971.

Trościński, Grzegorz. „Kancjonał radomskich bernardynów ze zbiorów Biblioteki Diecezjalnej w Sandomierzu. Z dziejów zasobu pieśni religijnych polskich franciszkanów obserwantów”. Piśmiennictwo zakonne w dobie staropolskiej, red. Magdalena Kuran, Katarzyna Kaczor-Scheitler, Michał Kuran, przy współpracy Dawida Szymczaka, Wydawnictwo UŁ, 2013, ss. 105-128.

Wöhler, Arnd. Die handschriftlichen Kantionale des Franziskus Valentin Ruthen (1674-1734). Untersuchungen zu Quellen und Aufbau katholischer Gesangbücher des späten Barock in Pomerellen. Böhlau, 1999. 
Zosim, Olga. „Katolicheskaya liturgicheskaya traditsiya i yeye znacheniye v razvitii vostochnoslavyanskoy dukhovnoy pesni XVII-XIX vekov". Chteniya Otdela russkoy literatury XVIII veka, vypusk 8, Al'yansArkheo, 2018, ss. 187-201.

\title{
DECYMA BAROKOWYCH PRZEKŁADÓW PIEŚNI O MARNOŚCI ŚWIATA (INC.: „CUR MUNDUS MILITAT SUB VANA GLORIA”) \\ STUDIUM ŹRÓDŁOZNAWCZE
}

\section{Streszczenie}

Artykuł zawiera edycję dziesięciu przekładów hymnu o inc.: „Cur mundus militat sub vana gloria”, przypisywanego Jacopone da Todi (ok. 1236-1306), które powstały w latach 1647-1747. Ich autorami są Jan Libicki (zm. 1670), Symeon z Połocka (1629-1680), Wespazjan Kochowski (1633-1700) oraz twórcy anonimowi.

Słowa kluczowe: marność świata; Jacopone da Todi; Jan Libicki; Symeon z Połocka; Wespazjan Kochowski

\author{
A DECIMA OF BAROQUE TRANSLATIONS OF SONGS \\ ABOUT THE VANITIES OF THIS WORLD \\ (INCLUDING “CUR MUNDUS MILITAT SUB VANA GLORIA”): \\ A STUDY OF SOURCES \\ Sum mary
}

This article contains the edition of ten Polish translations of a hymn about the vanity of the world, attributed to Jacopone da Todi (c. 1236-1306), and which were written in the years 1647-1747. Their authors were Jan Libicki (d. 1670), Symeon of Polotsk (1629-1680), Wespazjan Kochowski (1633-1700) and various anonymous poets.

Keywords: vanity of the world; Jacopone da Todi; Jan Libicki; Symeon of Polotsk; Wespazjan Kochowski 